\title{
ЕФЕКТИВНІСТЬ ОПЕРАЦІЙ АЗИГОПОРТАЛЬНОГО РОЗ'ЕДНАННЯ У ХВОРИХ ПРИ ЦИРОЗІ ПЕЧІНКИ ТА ВАРИКОЗНИХ ЗМІНАХ ВЕН СТРАВОХОДУ І ШЛУНКА
}

\author{
О. Ф. Дзигал, І. В. Савицький, О. М. Левченко, І. А. Анчева \\ Одеський національний медичний університет
}

\section{EFFICACY OF THE AZYGO-PORTAL DISCONNECTION OPERATIONS IN PATIENTS, SUFFERING HEPATIC CIRRHOSIS AND VARICOSE CHANGES IN GASTRO-ESOPHAGEAL VEINS}

\author{
O. F. Dzygal, I. V. Savytskyi, O. M. Levchenko, I. A. Ancheva \\ Odessa National Medical University
}

\section{Реферат}

Визначено ефективність хірургічної тактики у 67 хворих на цироз печінки (ЦП) з варикозними змінами вен стравоходу та шлунка з використанням операцій азигопортального роз'єднання (АПР). 3 приводу ЦП та варикозного ураження вен стравоходу і шлунка у пацієнтів 1-ї групи виконано стандартну операцію АПР Паціори з додатковою повною деваскуляризацією вен шлунка; у хворих 2-ї групи - операцію Паціори з частковою деваскуляризацією вен шлунка; у пацієнтів 3-ї - групи прошивання вен стравоходу і шлунка. Тривалість виконання операцій, об'єм інтраопераційної крововтрати вірогідно не різнилися в усіх групах. За частотою ускладнень та летальністю у безпосередньому та віддаленому післяопераційному періоді виражені переваги відзначені у 1-й групі. Доведено ефективність операцій АПР з приводу ЦП та варикозного ураження вен стравоходу і шлунка. За умови максимально повної деваскуляризації шлунка можливо суттєво зменшити частоту ускладнень, післяопераційної кровотечі та летальність.

Ключові слова: цироз печінки; варикозні зміни вен стравоходу і шлунка; азигопортальне роз'єднання; деваскуляризація; післяопераційні ускладнення.

Abstract

The surgical tactics efficacy was noted in 67 patients, suffering hepatic cirrhosis $(\mathrm{HC})$ with varicose changes in gastro-esophageal veins, using the azygo-portal disconnection (APD) operations. The standard APD operation according to Patsiora method with additiona complete devascularization of gastric veins, was done in the group I patients for $\mathrm{HC}$ and varicose affection in gastro-esophageal veins; in the group II patients - Patsiora operation with partial devascularization of gastric veins; in the group III patients - the gastroesophageal veins suturing. The operation duration and intraoperative blood loss did not differ in all the groups. Significant advantages in the group I were noted in the aspect of morbidity rate and lethality in immediate and remote postoperative period. Efficacy of the APD operations application for HC with varicose affection in gastro-esophageal veins was proved. In case of the maximally complete gastric devascularization performance it is possible to reduce the rate of morbidity, as well as of postoperative hemorrhage and lethality essentially.

Keywords: hepatic cirrhosis; varicose changes in gastro-esophageal veins; azygo-portal disconnection; devascularization; postoperative complications.

За даними статистики, захворюваність на ЦП різної етіології має тенденцію до збільшення [1, 2]; за результатами патологоанатомічних досліджень, вона сягає 11\% [1, 3]. Найчастішим та найбільш загрозливим ускладненням ЦП вважають портальну гіпертензію, наслідком якої при прогресуванні захворювання, неефективному лікуванні та/або принциповій неможливості виконання адекватного хірургічного втручання є кровотеча з варикозно-змінених вен стравоходу і шлунка $[2,4,5]$.

Единим клінічно ефективним i патогенетично обгрунтованим способом попередження стравохідношлункової кровотечі у таких хво- рих $є$ усунення змінених вен шляхом виконання хірургічних операцій, від формування портокавальних анастомозів (ПКА) до мініінвазивних втручань на варикозно-уражених венах стравоходу і шлунка.

Ефективність хірургічного лікування таких хворих дещо збільшилася, проте, ситуація не покращилася через велику кількість хворих на ЦП. Маючи достатній клінічний досвід, у певної кількості пацієнтів з приводу ЦП ми виконуємо операції ПКА [6], проте, такі втручання можливі лише за ЦП в стадії компенсації, решті хворих потрібні інші види хірургічного лікування. 3 огляду на це, ми обрали способи блокування можливості виникнення кровотечі з варикоз- но-змінених вен стравоходу і шлунка з деваскуляризацією принципових колатеральних шляхів кровопостачання цих органів. При цьому ми намагалися відповісти на запитання: які показання та протипоказання до виконання таких операцій з приводу ЦП у стадії компенсації та декомпенсації; який обсяг деваскуляризації шлунка і стравоходу; якою має бути тактика лікаря після операції; які можливі ускладнення у ранньому та віддаленому післяопераційному періоді.

Мета дослідження: аналіз ефективності хірургічної тактики у хворих на ЦП з варикозними змінами вен стравоходу і шлунка з застосуванням операцій АПР. 


\section{МАТЕРІАЛИ I МЕТОДИ ДОСЛІДЖЕННЯ}

Дослідження основане на ретроспективному аналізі історій хвороби 601 пацієнта, яких з приводу ЦП лікували в останні 10 років. 3 них відібрані 102 хворих з ЦП з варикозними змінами вен стравоходу та шлунка діаметром понад 5 мм. За класифікацією N. Soehendra, K. Binmoeller [7], це розширення відповідних судин 2-го ступеня, проте, ми використовували більш ретельну класифікацію, запропоновану А. Г. Шерцингером [8], більш зручну для ведення хворих при ЦП та варикозному ураженні вен стравоходу і шлунка. Для клінічних спостережень відібрані хворі з ЦП та варикозним ураженням вен стравоходу і шлунка 3-го ступеня.

Вік хворих від 42 до 61 року, жінок було 39 (58\%), чоловіків - 28 (41,8\%). Діагноз ЦП встановлювали на підставі даних клінічного обстеження хворих, результатів біохімічного аналізу крові, ультразвукового дослідження (УЗД) органів гепатопанкреатодуоденальної зони, комп'ютерної томографії, ендоскопічної ретроградної панкреатохолангіографії.

Проведена рандомізація хворих по групах за типом оперативного втручання. Операція АПР виконана у 67 пацієнтів, у 35 - ендоваскулярна емболізація вен шлунка. У 29 (43,3\%) хворих (1-ша група) виконана стандартна операція АПР Паціори 3 додатковою повною деваскуляризацією вен шлунка; у 17 (25,4\%) хворих (2-га група) - операція Паціори 3 частковою деваскуляризацією вен шлунка у зв'язку 3 неможливістю повної деваскуляризації через виражений процес, наслідки запальних захворювань органів черевної порожнини, загрозу пошкодження тканин селезінки та печінки, загрозу виникнення кровотечі, виражену кровоточивість, наявність коагулопатії, труднощі виділення судин з ризиком кровотечі $з$ них; у 21 (31,3\%) хворого (3-тя група) - лише прошивання вен стравоходу і шлунка (операція Паціори) без додаткової деваскуляризаціі.

Хворі розподілені за класифікацією тяжкості дисфункції печінки за Child-Pugh [9], ЦП у стадії компенсації відзначений у 7 (10,4\%), субкомпенсації - у 46 (68,7\%), декомпенсації - у 14 (20,9\%). Ми не включали у дослідження хворих на ЦП у IV стадіï, оскільки, з огляду на тяжкість їх стану, вважали таку вираженість патологічного процесу протипоказанням до виконання конкретного хірургічного втручання. Зауважимо, що ми дещо змінили класифікацію Child-Pugh, розділивши першу стадію на 2 стадії, визначивши хворих на ЦП в стадії субкомпенсації та компенсації. Отже, основним протипоказанням до виконання операцій АПР вважали наявність патологічного процесу в стадії декомпенсаціі; операцію вважали показаною за ЦП у стадії компенсації та певного збереження функціональної активності печінки, наявності у хворих варикозних змін вен стравоходу і шлунка з загрозою виникнення кровотечі, відсутності в анамнезі даних про хірургічну корекцію портальної гіпертензіі та лікування варикозно-уражених вен стравоходу і шлунка.

Перед операцією хворим проводили ендоскопічне дослідження функціонального стану варикознозмінених вен стравоходу і шлунка за наявності в анамнезі відомостей про гастроезофагеальну кровотечу (табл. 1).

Під час ендоскопічного дослідження звертали увагу на стан слизової оболонки стравоходу і шлунка, ступінь розширення і напруження вен, здатність вен розправлятися при інсуфляції повітря, вираженість трофічних змін стравоходу і шлунка (ознаки і ступінь езофаго- та гастропатіi).

Ефективність хірургічних втручань у групах хворих оцінювали за такими показниками: об'єм інтраопераційної крововтрати, наявність технічних труднощів під час операції та інтраопераційних ускладнень, тривалість операції. Оцінювали також особливості перебігу та частоту ускладнень в безпосередньому (протягом перебування хворих у стаціонарі) та віддаленому (до 3 років спо- стереження) післяопераційному періоді.

Отримані результати обробляли статистично. Відмінності вважали статистично значущими при $\mathrm{p}<$ 0,05 .

\section{РЕЗУЛЬТАТИ \\ ТА ÏХ ОБГОВОРЕННЯ}

Основним оперативним втручанням у хворих була операція Паціори, що передбачає виконання верхньої гастротомії, прошивання варикозно-уражених вен стравоходу і шлунка в місці кардіоезофагеального переходу з виходом на стравохід, а також кардії і субкардії в «шаховому» порядку з використанням абдомінального доступу.

Хворим 1-ї групи операцію Паціори доповнювали деваскуляризацією шлунка шляхом пересічення основних венозних колекторів, що здійснюють безпосередній зв'язок спленопортальної осі з варикозно-зміненими венами стравоходу і шлунка та зумовлюють високий тиск крові. Для цього пересікали короткі вени шлунка шляхом мобілізації шлунково-селезінкової зв'язки, починаючи з середньої третини шлунка по його великій кривині, включаючи дно до езофагокардіального переходу. Відводили шлунок вгору, виділяли і перев'язували у шлунково-панкреатичній зв'язці основний стовбур лівої вени шлунка, після чого здійснювали ревізію заочеревинного простору вище верхнього краю підшлункової залози у напрямку до задньої стінки шлунка, де пересікали гілки або основний стовбур задньої вени шлунка.

У хворих 2-ї групи обмежувалися частковою деваскуляризацією шлунка, проте, намагалися обов'язково блокувати ліву вену шлунка. На гастротомний отвір накладали двохрядний безперервний шов.

У 25 (86,2\%) пацієнтів 1-ї групи під час виконання операції здій-

Таблиця 1. Дані анамнезу щодо епізодів кровотечі у хворих на цП з варикозними змінами вен стравоходу і шлунка

\begin{tabular}{|c|c|c|c|c|c|c|}
\hline \multirow{3}{*}{ Групи хворих } & \multicolumn{6}{|c|}{ Наявність епізодів кровотечі в анамнезі } \\
\hline & \multicolumn{2}{|c|}{ немає } & \multicolumn{2}{|c|}{1} & \multicolumn{2}{|c|}{ понад 1} \\
\hline & абс. & $\%$ & абс. & $\%$ & абс. & $\%$ \\
\hline 1-ша (n = 29) & 4 & 13,8 & 7 & 24,1 & 18 & 62,1 \\
\hline 2-га (n=17) & 1 & 5,9 & 4 & 23,5 & 12 & 70,6 \\
\hline 3-тя $(n=21)$ & 2 & 9,5 & 4 & 19,0 & 15 & 71,5 \\
\hline Разом ... & 7 & 10,4 & 15 & 22,4 & 45 & 67,2 \\
\hline
\end{tabular}


Таблиця 2. Критерії, що характеризували інтра- та післяопераційні особливості операцій АПР у хворих на ЦП з варикозними змінами вен стравоходу і шлунка

\begin{tabular}{|c|c|c|c|c|c|}
\hline \multirow{2}{*}{ Групи хворих } & \multirow{2}{*}{$\begin{array}{c}\text { Середня } \\
\text { тривалість } \\
\text { операції, хв } \\
(\bar{x} \pm \mathrm{m})\end{array}$} & \multirow{2}{*}{$\begin{array}{c}\text { Середній об'єм } \\
\text { інтраопераційної } \\
\text { крововтрати, мл } \\
(\bar{x} \pm \mathrm{m})\end{array}$} & \multicolumn{2}{|c|}{$\begin{array}{c}\text { Частота } \\
\text { ускладнень }\end{array}$} & \multirow{2}{*}{ Померли } \\
\hline & & & абс. & $\%$ & \\
\hline 1-ша $(n=29)$ & $139 \pm 21$ & $245 \pm 32$ & 2 & 6,9 & - \\
\hline 2-га (n = 17) & $151 \pm 23$ & $368 \pm 44$ & 5 & 29,4 & 2 \\
\hline 3-тя $(n=21)$ & $132 \pm 20$ & $267 \pm 36$ & 7 & 33,3 & 1 \\
\hline
\end{tabular}

снювали дисекцію клітковини в ділянці кардії, куди підходять колатералі з заочеревинного простору, що є розгалуженням задньої вени шлунка; тобто, пересікали ліву та коротку вени шлунка, доступ до задньої вени шлунка був обмежений через ризик виникнення кровотечі. У 4 (13,8\%) пацієнтів 1-ї групи вдалося здійснити деваскуляризацію задньої вени шлунка. У хворих 2-ї групи виконали часткову деваскуляризацію вен шлунка, зокрема, повне пересічення короткої вени шлунка - у 3 (15,8\%), часткове пересічення короткої та додатково - лівої вени шлунка - у 16 $(84,2 \%)$.

Безпосередні дані, що дозволяють системно охарактеризувати технічні та клінічні особливості застосованих оперативних втручань, наведені у табл. 2. Тривалість операцій достовірно не різнилася у групах хворих. Об'єм інтраопераційної крововтрати у хворих різнився на $9-31 \%$, що було статистично незначущим.

Безпосередньо після операції у 2 (6,9\%) хворих 1-ї групи виникли ускладнення: нагноєння операційної рани та пневмонія, які були усунуті під час лікування пацієн- тів у стаціонарі. Всі пацієнти живі. У 2-й та 3-й групах ускладнення після операції виникли відповідно у 5 та 7 пацієнтів, померли 2 та 1 хворий. Вважаємо тяжкість клінічного стану хворих з суттєвим пригніченням функціональної активності печінки, дисфункцією органів гастропанкреатодуоденальної зони та формуванням поліорганної недостатності основними причинами появи ускладнень та летальності у безпосередньому післяопераційному періоді. Проте, відзначаємо відсутність критичної кровотечі після операції, що є непрямим свідченням ефективності хірургічного лікування.

Протягом 3 років спостереження всі пацієнти 1-ї групи живі, у 2-й групі - померли 4 хворих, у 3-й групі - 3. Причиною смерті 2 хворих 2-ї групи була повторна кровотеча на тлі печінкової (в 1) та поліорганної (в 1) недостатності, що прогресувала. В 3-й групі хворий помер внаслідок повторної шлунково-кишкової кровотечі (він продовжував зловживати алкоголем).

Таким чином, вважаємо принципово кращим методологічним прийомом під час хірургічного лікуван- ня хворих з приводу ЦП з ризиком виникнення кровотечі з варикознозмінених вен стравоходу і шлунка повну деваскуляризацію шлунка поряд з операцією Паціори. Результати в безпосередньому та віддаленому післяопераційному періоді свідчать на користь виконання повної деваскуляризації шлунка, порівняльні дані застосованих критеріїв у хворих 1-ї та 2-ї груп переконують в цьому.

Аналізуючи одержані дані, слід відзначити ефективність операцій АПР при хірургічному лікуванні хворих з приводу ЦП з варикозними змінами вен стравоходу і шлунка. За умови максимально повної деваскуляризації шлунка можливо суттєво зменшити частоту ускладнень, післяопераційної кровотечі, летальність. Інтерес викликає місце операцій АПР при лікуванні пацієнтів з приводу тяжких захворювань печінки: ми вважаємо застосовані операції методом паліативного хірургічного лікування, які, насамперед, не мають на меті безпосереднє усунення ЦП. Фахівці, які обирають хірургічну тактику виконання операцій з роз'єднання судин, мають володіти неабияким клінічним досвідом для якнайшвидшого їх здійснення та мінімізації травмування внутрішніх органів.

Позитивні критерії, що характеризують особливості виконання операцій АПР, слід мати на увазі під час вибору тактики хірургічного лікування хворих з приводу ЦП за високого ризику виникнення кровотечі 3 варикозно-змінених вен стравоходу і шлунка.

\section{ЛITEPATYPA/REFERENCES}

1. Ivashkina VT, redaktor. Bolezni pecheni i zhelchevyvodjashhih putey: rukovodstvo dlya vrachey. Moskva: M-Vesti; 2005. 478 s. [In Russian].

2. Alekseeva OP, Kurysheva MA. Cirroz pecheni i ego oslozhnenija. N. Novgorod: Izd-vo Nizhegorod. gos. akademii; 2004. 96 s. [In Russian].

3. Ibadildin AS, Andreev GN, Borisov AE. Polisindromnost cirroza pecheni. Velikiy Novgorod; 1999. 196 s. [In Russian].

4. de Franchis R, Baveno VF. Revising consensus in portal hypertension: report of the Baveno $\mathrm{V}$ consensus workshop on methodology of diagnosis and therapy in portal hypertension. J Hepatol. 2010;53(4):762-8.

5. Šilkauskaitè V, Pranculis A, Mitraitè D, et al. Hepatic venous pressure gradient measurement in patients with liver cirrhosis: a correlation with disease severity and variceal bleeding. Medicina (Kaunas). 2009;45(1):8-13.
6. Dzyhal OF, Hrubnik YuV. Rozvytok systemnykh dysfunktsii orhaniv ta rehuliatornykh mekhanizmiv u hvoryh na tsyroz pechinky iz suputnim astsytom. Odeskyi medychnyi zhurnal. 2017;(1):45-50. [In Ukrainian]

7. Soehendra N, Binmoeller KF. Is sclerotherapy out? Endoscopy. 1997;29(4):283-4.

8. Shercinger AG. Patogenez, diagnostika, profilaktika i lechenie krovotecheniy iz varikoznyh ven pishhevoda i zheludka u bolnyh s portalnoy gipertenziey [tezisy]. Moskva; 1986. 32 s. [In Russian].

9. Reddy SS, Civan JM. From Child-Pugh to Model for End-Stage Liver Disease: Deciding Who Needs a Liver Transplant. Med Clin North Am. 2016;100(3):449-64. 